\title{
The Irony in Ang Lee's Life of Pi
}

\author{
Kriswanda Krishnapatria
}

Universitas Padjadjaran

e-mail: kriswanda.krishnapatria@unpad.ac.id

\begin{tabular}{ccc}
\hline Diterima & Direvisi & Disetujui \\
$16-01-2021$ & $03-03-2021$ & $08-03-2020$ \\
\hline
\end{tabular}

\begin{abstract}
This paper investigates and analyses the irony in Ang Lee's movie: Life of Pi (2012). Irony is a language (or pictorial in film) style used as a subtle insinuation as well as contains statements that are very contradictory or inversely proportional to the existing reality. There has not been very much work devoted to exploring what it means either to discover irony in movies or to best interpret it, and that is what this article attempts. Conventionally, there are three most commonly used irony in literature, which are verbal (or communicative), situational, and dramatic. The research method applied is descriptive analytic to describe the meaning and context of irony found in Life of Pi. The conclusion is that Ang Lee's Life of Pi is full of situational irony, thus makes it fascinating to watch and to discuss. Besides, dramatic irony was also found, and it was applied in order to preserve the audience interest's, provoke curiosity, and make a contrast between the situation of the characters and the later scene that ultimately unfolded. This paper also shows that the cinematographic aspect related to the analysed narration could dramatically add insightful meanings to the irony.
\end{abstract}

Keywords: Irony, Life of Pi, cinematography

Abstrak - Artikel ini berusaha meneliti dan menganalisis konsep ironi dalam film Life of Pi (2012) karya Ang Lee. Ironi merupakan sebuah gaya bahasa (atau gaya visual dalam film) yang digunakan sebagai sindiran halus atau mengandung makna yang sangat kontradiktif atau berbanding terbalik dengan kenyataan yang ada. Hingga saat ini, tidak banyak penelitian yang dikhususkan untuk mengeksplorasi tentang penemuan ironi dalam film atau menafsirkannya dengan baik, dan artikel ini mencoba untuk mengisi kekosongan tersebut. Lebih jauh, ada tiga jenis ironi yang paling sering digunakan dalam karya sastra, yaitu ironi verbal (atau komunikatif), situasional, dan dramatis. Metode penelitian yang digunakan dalam penelitian ini adalah deskriptif analitik yang bertujuan untuk mendeskripsikan makna dan konteks ironi yang terdapat dalam film Life of Pi. Kesimpulan yang didapatkan adalah film Life of Pi karya Ang Lee didominasi oleh kemunculan ironi situasional, sehingga membuatnya menarik untuk ditonton dan didiskusikan. Selain itu, ironi dramatis juga ditemukan, dan poin ini diterapkan untuk menjaga minat penonton, memancing rasa ingin tahu, serta membuat kontras antara keadaan tokoh dan adegan selanjutnya yang akhirnya terungkap. Artikel ini juga menunjukkan bahwa aspek sinematografi yang terkait dengan narasi yang dianalisis dapat secara dramatis menambah makna mendalam pada ironi tersebut.

Kata kunci: Ironi, Life of Pi, sinematografi

\section{INTRODUCTION}

MacDowell (2016) argued that American narrative cinema depicts a productive foundation for the discussion of irony in film. In the $85^{\text {th }}$ Academy Awards (commonly referred to as Oscars), Life of $P i$, directed by Ang Lee, received four notable awards for best direction, cinematography, visual effect and original score (music) due to its abundant aural and visual resources. Many discussions about the film are stimulated by its plot on the relationship between the main character Pi and the tiger Richard Parker, and it comes as no surprise that the story about Indian Tamil boy from Pondicherry exploring themes of spirituality emerged as a critical and commercial success (Brooks, 2013).
In fact, the original writer Yann Martel considered the movie as a pleasant adaptation, stating he was happy the written work could be adapted so well as a film. Even though the conclusion of the movie is not as puzzling as the novel's, the alternate version of Pi's story surprisingly arrives at the audience and raises the same important questions about truth, acknowledgement and faith (Quill, 2012).

Considering its notable facts, Ang Lee's Life of $P i$ has started to gain scholars and researchers' interest by focusing upon its strong spiritual themes. The novel itself has been extensively studied by researchers, but the movie adaptation has not yet gained the same achievement. Stephens (2010) examined the original novel's narrative from both 
religious and science perspectives. In the end, he concluded that there are two alternate stories that could inspire two different types of reader: secular and religious one. In addition, Cheng and Liu (2014) set their research as a film discourse using semiotic modalities. They argued the relationship between the two protagonists are mostly determined by Pi's attitude toward Richard Parker.

Despite the fact that the movie adaptation has also been widely investigated, in-depth analysis of irony concept equipped with cinematography approach in the movie is still rarely studied. Generally speaking, writers may utilise irony to make their readers break and ponder what happens and what has just been stated in the story, or to highlight a main theme (Cadden, 2000). Last but not least, Thorn (2015) used some approaches from multiculturalism to psychoanalysis in analysing the content of the movie. He summed up that Pi's cannibalism is sublimated into a story of a boy and four animals on a lifeboat.

From the given studies above, none employed irony in analysing the movie. It is possible that irony as one of many language styles in literature is variously used in a film in order to obtain certain effects. Whether realised or not, the presence and the interpretation of irony in a narrative is expected to impact on the overall meaning of a particular scene or the film itself as a whole in which thoughts and feelings from the narrative could be uniquely conveyed.

Furthermore, a much-debated subject in other disciplines, in film scholarship irony is habitually referred to but too seldom explored (MacDowell, 2016). Thus, this study primarily aims to fill the gap by investigating the ironic potential in a movie, which is Life of Pi (2012), and the following question guide this study: what ironies are presented in Ang Lee's Life of Pi, and what their meanings are. This research question aims to capture the irony and its meaning in the story with the use of cinematography approach like mise-en-scene. Further, this study is expected to be able to contribute to a better understanding of how irony as literary device impacts audience in perceiving a movie through different lenses.

\section{RESEARCH METHOD}

The method applied in this research was descriptive analytic as well as dialogue analysis to describe the irony context along with the meaning in Ang Lee's Life of Pi. The concept of irony (verbal or communicative, situational, and dramatic) analysed in this paper is based on (MacDowell, 2016),
Abrams and Harpham (2011) as well as Arp and Johnson (2008). This research was conducted in two steps: first, discussion of the irony presented in the film based on chronological order and second, examining the irony found in the film from cinematographic aspects.

To complete and provide additional lenses to irony analyses in this research, cinematography approach was essentially equipped, for the medium of the research object is a movie. To limit the scope, this study only focuses on the film's mise-en-scene. Mise-en-scene refers to all visual elements of a film production within the space provided (Lathrop \& Sutton, 2014). Among important aspects of mise-enscene are setting, lighting, and movement of actors. Mise-en-scene is often recognised as an essential part of the creative process, and in order to control it, the director must stage the event for the camera (Stam, 2017). It is expected that through the mentioned methods above the irony and its meaning can be thoroughly explained.

\section{RESULTS AND DISCUSSION}

The author chronologically describes the scenes that have been analysed using the concept of irony that was mentioned earlier. Each scene will be first given an explanation of the irony type through the narrative or story aspect; then the intended image is added and ends with a discussion of the cinematographic aspect to obtain more insightful meaning.

\section{Piscine got his nickname "Pi"}

Pi was tired of having his name Piscine mocked and teased with "pissing" (urinating) by both his classmates and schoolmates. Therefore, the first irony occurred when Pi stood up and wrote his name on the blackboard in the beginning of a semester at school. This was an example of situational irony, for this incident was unexpected, and this is the story of how Pi eventually got his nickname "Pi". In this scene Pi's actions produced effects that are different from what the viewers might have expected. Normally, after what had happened earlier viewers may think that the teacher would try to stop Pi's actions or that other students once again would make fun of him, but neither did happen. 


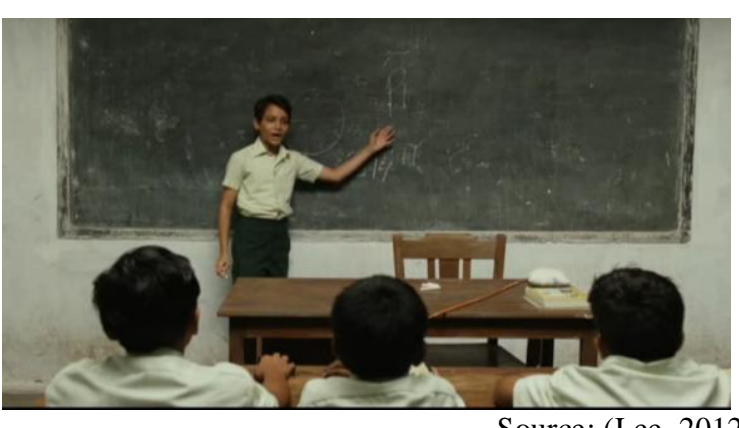

Figure 1. Piscine introduced his nickname, "Pi" (Life of Pi, 00:07:40 - 00:08:20)

In terms of cinematographic aspect, the placement of the camera was arranged in such a way that it felt as if $\mathrm{Pi}$ was acting as a teacher in the class and the audience carefully listened to the explanation he was giving. The camera is in the Eye level position - that is, the camera is the same height as the subject level or if the subject is standing/sitting the camera is in the same axis as the subject position $(\mathrm{Pi})$. This is essential to strengthen Pi's position in the classroom and ultimately to pave his way as a "school legend" as he was momentarily taking in charge of the brief introduction after the prior bullies by his friends. The type of shot used was medium shot, which is a general, all-purpose shot (Ablan, 2002). The medium shot was used for a series of dialogue involving $\mathrm{Pi}$ and his classmates, and it allowed the audience to pick up on Pi's movements and gestures. His body language was essential to convey his self-assurance, and the shot remained close enough to capture that emotion.

\section{Practicing three faiths}

Pi constantly struggled in finding his way to find God. At first, he was Hindu due to parents' connection, and later on he also found God's love in Christianity. His parents did not know about Pi's journey in searching of God nor they knew when it would end. However, the audience know the secret that $\mathrm{Pi}$ was constantly practicing different religious beliefs, thus, creating a dramatic irony. This dramatic irony occurred when the audience knew the three religions that $\mathrm{Pi}$ followed that other characters (Pi's family) did not. This very moment was necessarily important in the story because the irony preserved the audience interest's, provoked curiosity, and made a contrast between the situation of the characters and the later scene that ultimately unfolded.

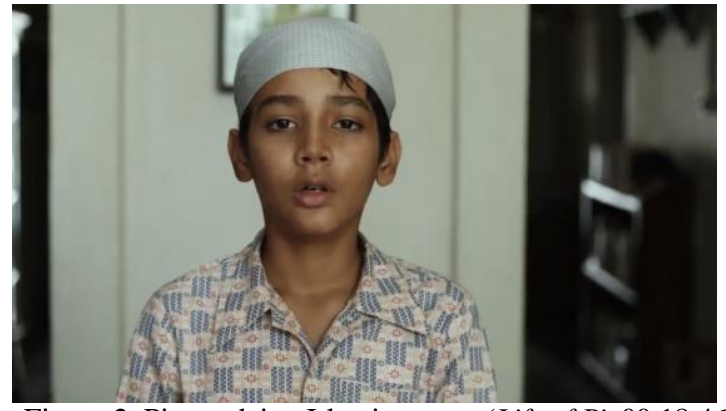

Figure 2. Pi was doing Islamic prayer (Life of $\mathrm{Pi}, 00: 18: 46$ )

Pi was believing in his ancestor religion Hinduism and then baptized into a Christian while practicing Islam. When his father finally discovered his son's religious doings, Pi was advised by his father's memorable quote: "Because believing in everything at the same time is the same as not believing in anything."

\section{The storm and sinking of Tsimtsum}

The thunder and lightning presence in the film indeed feels cliché, but the real sea storm is one of natural phenomena that will definitely make the audience shudder. Pi was seen sliding to the bottom of the deck, holding the railing handrails, then swimming along the flooded corridor to try to save his family. Having been forced to abandon the ship with a lifeboat, the subsequent scene when Pi despite the middle of the big ocean waves kept jumping into the water and seeing the ship sinking from under the sea is something ironic. This is another situational irony because the audience is expected to feel the grief knowing that Pi lost all his family members who drowned in the ship. Yet, viewers would surprisingly feel amazed and stunned by the cinematographic visual beauty.

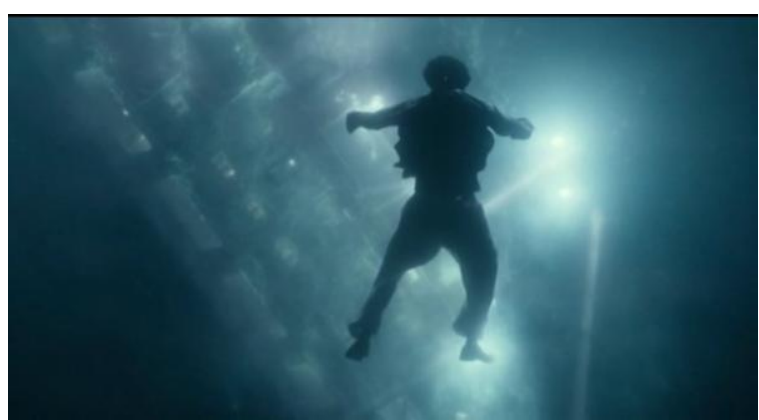

Figure 3. A breath-taking, yet heart-breaking scene (Life of $P i, 00: 43: 25)$

The camera is set to the position of the point of view in which Pi acts as a subject looking at the sinking of the Japanese cargo ship Tsimtsum due to the sea storm. Any audience will be amazed when they see this stunning scene. The type of shot used is long shot to stress the setting under the sea as well as to show $\mathrm{Pi}$ in shocked silence. Additionally, the lighting used is tungsten or room lighting to provide a dramatic effect in the story. From the 
cinematographic aspect, it goes without saying that it is ironically one of the best scenes in the film.

3. Richard Parker in the lifeboat was what made Pi survive

The biggest irony of this story is probably the presence of a feral and wild tiger in the lifeboat is exactly the reason why $\mathrm{Pi}$ remained alive for 7 months afloat. Pi was thrown into a lifeboat by the crew along with a hyena and a zebra, but then he rescued Richard Parker from drowning before he noticed what he was doing. Having a powerful carnivore like tiger in the lifeboat has made the hyena not to prey on Pi and killed the zebra, and later orangutan, instead. Richard Parker also gave Pi a cause to live, for he had to feed Richard Parker, and he could not just give up. Adult Pi remarked, "without Richard Parker, I would have died by now. My fear of him keeps me alert. Tending to his needs gives my life purpose." Thus, this scene can be considered as a situational irony, because living with the tiger was exactly what made Pi a survivor instead of losing his life just like adult Pi later stated: "Richard Parker, my fierce companion, the terrible one who kept me alive..."

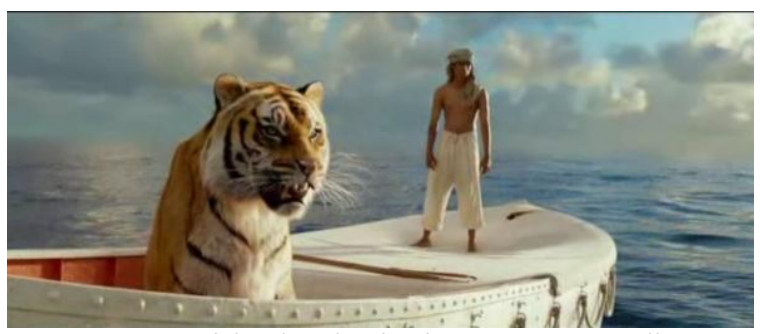

Figure 4. Richard Parker is Pi's reason to stay alive

The scenes of Pi living together with Richard Parker began after the sinking of Tsimtsum and ended when they parted on the Mexican coast. These are the dominant scenes throughout the narrative, and varied camera placements were utilised ranging from high angle to low angle to show the tough journey they both made through the ocean.

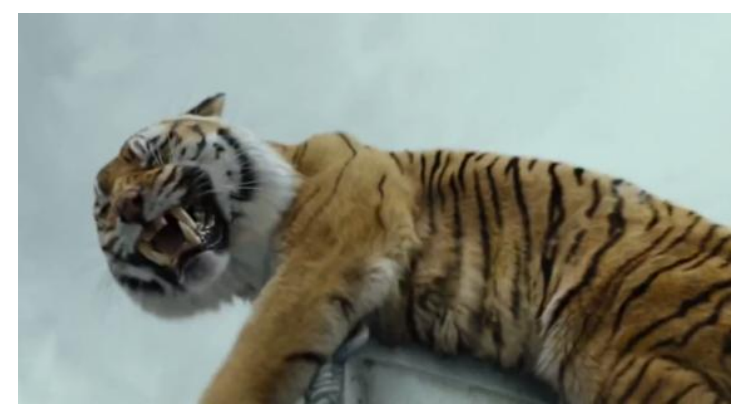

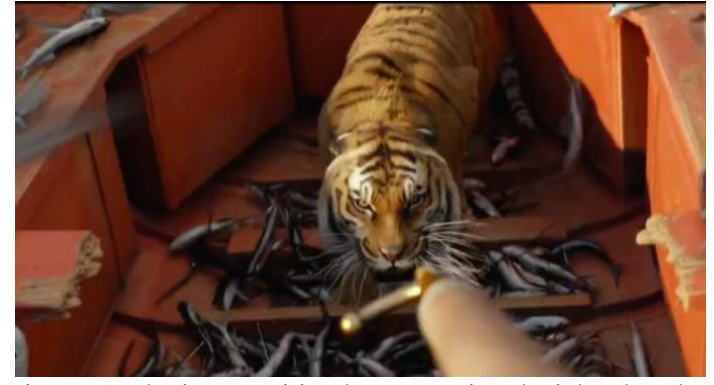

Figure 5. The juxtaposition between Pi and Richard Parker (Life of Pi, 01:15:46)

In the first image of figure 5, initially the camera is in the low angle with Richard Parker as the subject trying to pounce on Pi to show that he is the most powerful creature in the lifeboat. As the story went on, Pi successfully utilised existing device to tame Richard Parker like in the second image. Conversely, the camera is in a high angle position to show that $\mathrm{Pi}$ was then in more superior position in giving orders from this moment onwards. Most of the shots used in these notable scenes are close-up shots in order to tightly frame Richard Parker's face, showing his shifted reaction from being savage to submissive as the main focus in the two frames. Lighting used in the scenes mostly is daylight to depict open competition between $\mathrm{Pi}$ and Richard Parker in dominating the lifeboat. The same lighting also allows viewers to clearly see Richard Parker's facial expression that ultimately, the beast was forced to accept $\mathrm{Pi}$ as another ruler of the rescue boat, creating an uneasy truce between them.

4. The lifeboat is spacious, yet it was awfully 'crowded'

Another situational irony is when realising Pi's life in the lifeboat with Richard Parker, the tiger. It can be clearly seen that the lifeboat was designed to accommodate dozens of people. It would have been merrier had Pi shared it with other passengers, yet there were ultimately only two of them, and ironically it was awfully crowded. It is a sarcastic statement that the lifeboat could have accommodated more because it seems that Pi was feeling like he did not have enough room as it should be: "It's time to settle this. If we're going to live together, we have to learn to communicate" (Pi's voice-over for the tiger).

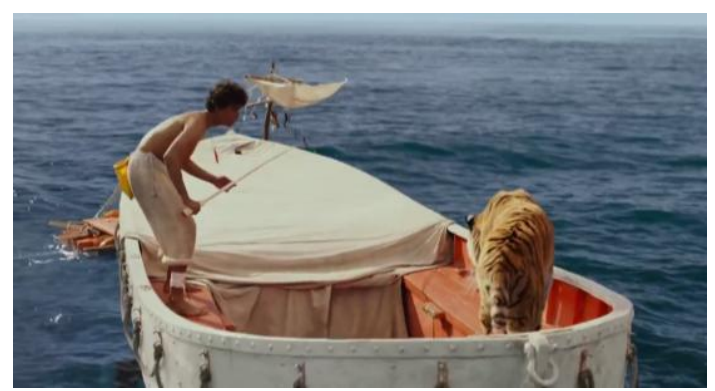

Figure 6. Pi struggled to share places with Richard Parker in the lifeboat (Life of Pi, 01:17:32) 
The unexpected twist to the discovery that dozens of individuals could have been on the boat with $\mathrm{Pi}$ is indeed ironic. On the above figure, the camera is positioned on eye-level angle. It is regarded to be sentimentally unbiased and is chiefly employed for direct, realistic presentation between Pi-Parker relationship in the boat. The natural light helps the audience in watching Pi's necessity in constantly fighting for his place over the boat with Richard Parker despite its roomy state.

\section{Landing on the Algae Island}

This part could be seen as Pi's and Richard Parker's last journey in the story. When Pi was so desperate that he thought of giving up, suddenly an island appeared. At first, Pi was uncertain whether the island was real or not, and later he discovered that the mysterious island was actually made of algae in high density instead of soil.

When Pi initially decided to land on the algae island, he was thinking of settling and resting from their journey on this island for good. This can ben seen when he tied the precious bracelet given by Anandi, Pi's girlfriend, to a tree root upon his landing on the island. However, Pi found the truth that the island was too good to be true for a paradise and realised that at night the island turned into an acidic carnivorous island devouring anything in the water.

$\mathrm{Pi}$ then came to a sense that staying at the island mean imminent death to him, so he refused to set the island as his final resting place and headed to the lifeboat to continue the journey with the tiger. It turns out that the island itself is a situational irony since it was not a paradise like he thought at first. Despite being resourceful and peaceful with the abundant meerkats and scarce fresh water in the island, Pi saw the island as a coffin waiting for him to enter.

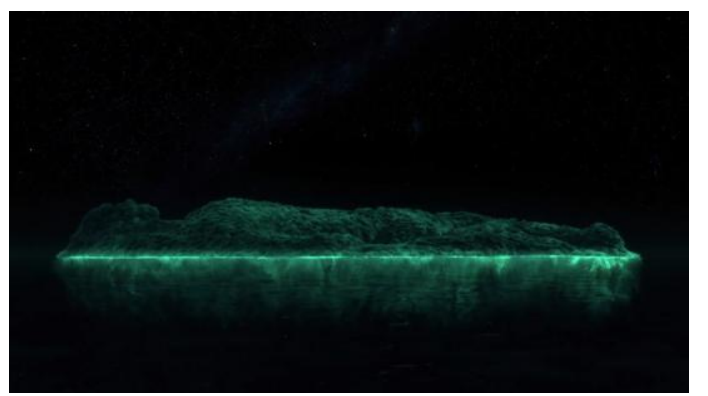

Figure 7. The human-shaped algae island (Life of Pi, 01:40:23)

Upon discovering human tooth wrapped in a fruit-like leaves, a wide long shot was used in the movie to show the audience what the island actually looked like. Apparently, the algae island was shaped like a human body. This strengthens the danger lies within the island itself as a carnivorous and deadly one. It was such an irony that the island of algae which nourished Pi and Richard Parker were also trying to consume them in return. Despite its artistically attractiveness, the bitter truth behind the island made Pi continue his journey, or else he would have been like the island itself: lying down dead.

\section{Pi's goodbye to Richard Parker}

After being adrift in the ocean for 227 days, Pi finally arrived at the coast of Mexico. His body was so thin and shabby that he collapsed from the long journey upon his long-awaited arrival on the beach. When his consciousness began to disappear, at that very moment, he saw Richard Parker leaving the boat and walking along the shore to the jungle. Just before entering the woods at the edge of the jungle, Richard Parker stopped. Pi and the audience should have been certain that Richard Parker was going to look back at his former master, had his ears flattened, and growl-that the tiger would bring their bond to an end ceremoniously or in some way. Yet he just stared ahead into the jungle and disappeared for good from Pi’s life.

Interestingly, two ironies emerged in this scene. First, that Pi was broken hearted after Richard Parker left him is a situational irony. This is primarily because most viewers including Pi himself thought that Richard Parker would at least turn towards $\mathrm{Pi}$ as a sign of parting after their epic survival; it did not happen, so this event was really unexpected, making it as an irony. Secondly, Richard Parker who looked bony and limp also presented a situational irony in which his dignity and pride as a tiger, the ruler of the jungle, became invisible. Similarly, in the end of the journey $\mathrm{Pi}$ once again looked malnourished despite his recovery in the algae island.

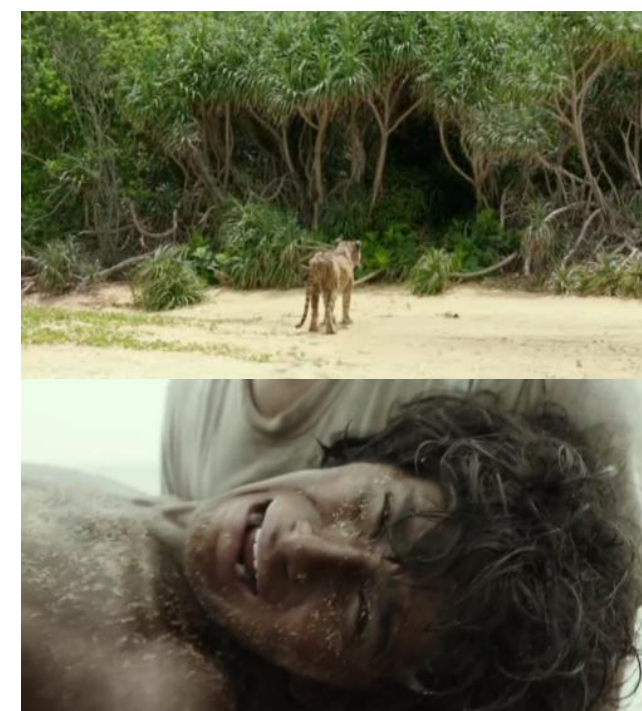

Figure 8. Clumsy Richard Parker and Pi weeping (Life of Pi, 01:45:00 - 01:45:59)

The placement of the camera on above scene is set to the eye level position because in the initial 
narration it is told that superior Richard Parker eventually became Pi's companion. They became two creatures that have a symbiotic relationship of mutualism. The types of shots used are long shot on Richard Parker and close-up on Pi. In this scene, the long shot was used to show Richard Parker in relation to the surroundings, returning to his original habitat from so much time spent at sea. The close-up shot on Pi was to clearly show him crying over the parting with his fierce companion. In addition, lighting used on both frames was daylight to emphasize the dramatic effect presented in the film.

\section{CONCLUSION}

Undoubtedly, one of literary devices frequently used in Ang Lee's Life of Pi is irony. This irony brings some additional meanings to particular situation or scene in the film. Ironical scenes and situations in film could grow audiences' curiosity for a better understanding in appreciating the screen work. Ironies made literary works more dramatic, and bring the audience to imagine as well as to comprehend the implied meanings of the story from the motion picture.

The irony in Ang Lee's Life of Pi is clearly seen when referring to the definition of the concept of irony itself. Of three types of irony, situational irony is dominantly presented in each discussed scene. In fact, two situational ironies could even emerge simultaneously in a scene. From the technical perspective, cinematographic aspect of mise-en-scene such as lighting and camera angle are essential elements in strengthening the irony and its meaning through the story of the movie.

Despite these research merits, there are still gaps to fill for further research like how other literary devices like symbolism could be analysed in Ang Lee's Life of Pi. Alternatively, scholars can conduct deeper and further study concerning the irony concept with other cinematic approach in the movie.

\section{REFERENCES}

Ablan, D. (2002). Digital cinematography \& directing: New Riders.

Abrams, M. H., \& Harpham, G. (2011). A glossary of literary terms: Cengage Learning.

Arp, T. R., \& Johnson, G. (2008). Perrine's Story and Structure: An Introduction to Fiction.
Brooks, X. (2013, 25 February). Ang Lee wins best director Oscar for Life of Pi. The Guardian. Retrieved from https://www.theguardian.com/film/2013/feb 125/ang-lee-best-director-oscar-life-of-pi

Cadden, M. (2000). The irony of narration in the young adult novel. Children's Literature Association Quarterly, 25(3), 146-154.

Cheng, Y., \& Liu, W. (2014). A multimodal discourse analysis of the relationship between $\mathrm{Pi}$ and Richard the tiger in the movie Life of Pi. International Journal of Language and Literature, 2(4), 191-219.

Lathrop, G., \& Sutton, D. O. (2014). Elements of mise-en-scene. Retrieved on January, 3.

Lee, A. (Writer). (2012). Life of Pi. In G. Netter, A. Lee, \& D. Womark (Producer): 20th Century Fox.

MacDowell, J. (2016). Irony in film: Springer.

Quill, G. (2012). Yann Martel on Life of Pi: Author gives 3D movie by Ang Lee thumbs up. Retrieved from https://www.thestar.com/entertainment/book s/2012/11/23/yann_martel_on_life_of_pi_au thor_gives_3d_movie_by_ang_lee_thumbs_ up.html

Stam, R. (2017). Film theory: an introduction: John Wiley \& Sons.

Stephens, G. (2010). Feeding Tiger, Finding God: Science, Religion, and "the Better Story" in Life of Pi. Intertexts, 14(1), 41-59.

Thorn, M. (2015). Cannibalism, Communion, and Multifaith Sacrifice in the Novel and Film Life of Pi. The Journal of Religion and Popular Culture, 27(1), 1-15. 